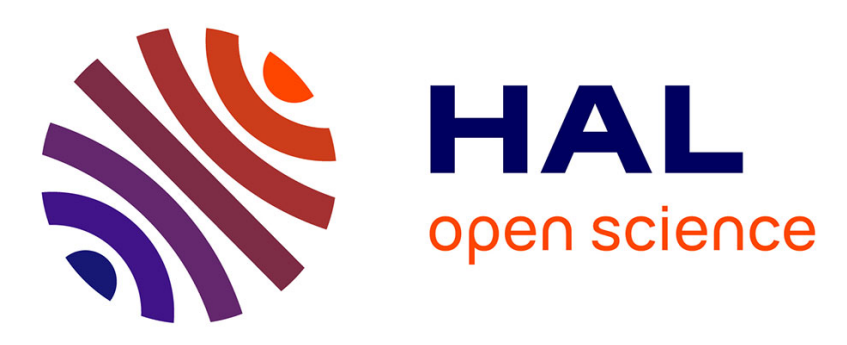

\title{
Elaboration of III-V top cell for tandem cell with Silicon
}

Amadeo Michaud, Ahmed Ben Slimane, Adrien Bercegol, Raphaël Lachaume, Jean-Christophe Harmand, Jara Fernandez Martin, Stéphane Collin

\section{To cite this version:}

Amadeo Michaud, Ahmed Ben Slimane, Adrien Bercegol, Raphaël Lachaume, Jean-Christophe Harmand, et al.. Elaboration of III-V top cell for tandem cell with Silicon. 2019 IEEE 46th Photovoltaic Specialists Conference (PVSC), Jun 2019, Chicago, United States. pp.1034-1038, 10.1109/PVSC40753.2019.8980524 . hal-03084896

\section{HAL Id: hal-03084896 https://hal.science/hal-03084896}

Submitted on 21 Dec 2020

HAL is a multi-disciplinary open access archive for the deposit and dissemination of scientific research documents, whether they are published or not. The documents may come from teaching and research institutions in France or abroad, or from public or private research centers.
L'archive ouverte pluridisciplinaire HAL, est destinée au dépôt et à la diffusion de documents scientifiques de niveau recherche, publiés ou non, émanant des établissements d'enseignement et de recherche français ou étrangers, des laboratoires publics ou privés. 


\title{
Elaboration of III-V top cell for tandem cell with Silicon
}

\author{
Amadéo Michaud ${ }^{1}$, Ahmed Ben Slimane ${ }^{2}$, Adrien Bercegol ${ }^{3}$, Raphael Lachaume ${ }^{2}$, Jean-Christophe \\ Harmand ${ }^{4}$ Jara Fernandez Martin ${ }^{1}$, Stéphane Collin ${ }^{2,4}$ \\ 1 TOTAL GRP, Palaiseau, 91120, France \\ 2, France Institut Photovoltaïque d'Ile-de-France (IPVF), Palaiseau, 91120, France \\ 3 EDF R\&D, Palaiseau, 91120, France
}

\begin{abstract}
4 Centre de Nanosciences et de Nanotechnologies (C2N), CNRS, Université Paris-Sud/Paris-Saclay, 91120, France

amadeo.michaud@total.com
\end{abstract}

\begin{abstract}
We study GaInP alloy grown by molecular beam epitaxy (MBE) for single junctions solar cells. Growth was optimized to obtain a photo-conversion efficiency of $9.66 \%$, without anti-reflection coating. Further characterization allowed the investigation of the remaining issues in the structures. Beryllium doped GaInP base layer was identified as the layer limiting the photo-conversion performance of the solar cells.

Index Terms - III/V semiconductor, Silicon, tandem solar cells, GaInP, MBE.
\end{abstract}

\section{INTRODUCTION}

Much research effort is currently dedicated to overcome the Shockley-Queisser limit. One of the main lead is III-V/Silicon tandem cell. In a two terminal tandem design with a $\mathrm{Si}$ bottom cell, ideal top cell has a $1.73 \mathrm{eV}$ bandgap and allows to reach a $41.9 \%$ theoretical efficiency [1]. By adjusting their composition, $\mathrm{Ga}_{\mathrm{x}} \mathrm{In}_{1-\mathrm{x}} \mathrm{P}$ and $\mathrm{Al}_{\mathrm{y}} \mathrm{Ga}_{1-\mathrm{y}} \mathrm{As}$ alloys approach this optimal bandgap, they are good candidates and can be grown on GaAs substrate.

$\mathrm{Al}_{\mathrm{y}} \mathrm{Ga}_{1-\mathrm{y}} \mathrm{As}$ has a $1.73 \mathrm{eV}$ bandgap with $\mathrm{y}=0.25$, but it suffers from significant oxygen incorporation during the growth causing deep levels acting as recombination centers in the device[2] . Thanks to its lower sensitivity to oxygen, better efficiencies are currently obtained with $\mathrm{Ga}_{\mathrm{x}} \mathrm{In}_{1-\mathrm{x}} \mathrm{P}$ based solar cells grown with metalorganic chemical vapor deposition (MOCVD). Indeed single junction GaInP cell reached an efficiency of $20.8 \%$ [3], Essig et al assembled a four terminals $\mathrm{GaInP} / \mathrm{Si}$ tandem showing an efficiency of $32.45 \%$ [4], a photoconversion of $33.3 \%$ was reached using wafer bonding with a triple junctions GaInP/GaAs//Si tandem cell [5].

However, when lattice matched to GaAs substrates, $\mathrm{Ga}_{0.51} \mathrm{In}_{0.49} \mathrm{P}$ properties vary with the growth conditions. Bandgaps from 1.83 to $2 \mathrm{eV}$ were reported at this composition [6]. Moreover, atomic ordering [6] is often observed in this alloy, inducing carrier lifetime variation [7] and carriers diffusion anisotropy [8].
Here we focus on the impact of MBE growth conditions on GaInP properties and report their effect on GaInP cells. We then identify the main drawbacks related to Be-doping and $\mathrm{P}$ solid source used for the growth of phosphide alloys.

\section{EXPERIMENTAL RESULTS}

III-V semiconductors samples were grown by a Riber Compact $21 \mathrm{MBE}$. Beryllium and Silicon, serve as $\mathrm{p}$, and ndopant, respectively. GaInP characterization layers and single junction solar cells were grown on (100) GaAs substrate.

Solar cells comprise a $1 \mu \mathrm{m}$ p-GaInP absorber, an AlInP window, a $50 \mathrm{~nm}$ n- GaInP emitter, AlGaInP back surface field and GaAs contacts layer (Fig. 1), they are processed via wet etching. $\mathrm{Ni} / \mathrm{Ge} / \mathrm{Au}$, and $\mathrm{Ti} / \mathrm{Au}$, metallic contacts allow the formation of ohmic contacts with the cell. Various characterizations on AlInP passivated p-doped GaInP enabled the material optimization for photovoltaic application.

Cells are characterized under AMG 1.5 illumination from an Oriel solar simulator, external quantum efficiency (EQE) is measured with a monochromator using a Si reference cell.

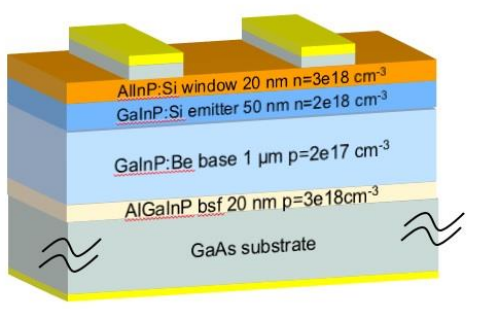

Fig. 1. Optimal GaInP solar cell structure in this study 
As said earlier growth conditions have significant impact on phosphides properties. Here we study the influence of the growth temperature Tg and the V/III ratio on GaInP. The goal is to maximize the PL efficiency of the GaInP, as it is a sign of better material quality and promotes photon recycling in the cells. The growth rate was maintained at $1 \mu \mathrm{m} / \mathrm{h}$ for all samples, $\mathrm{V} / \mathrm{III}$ ratio was varied by modifying the value of the beam equivalent pressure of phosphorus BEP(P). Two series of sample were grown, first a batch at a fixed V/III ratio of 12 and growth temperatures from $450^{\circ} \mathrm{C}$ to $580^{\circ} \mathrm{C}$. Then a batch with fixed growth temperature of $500^{\circ} \mathrm{C}$ and a V/III ratio varied between 12, 7.3 and 4.5.

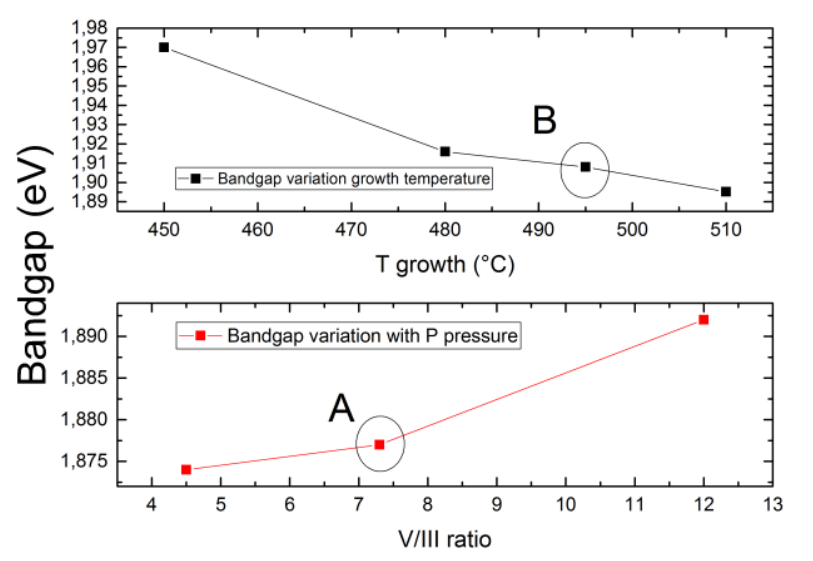

Fig. 2. Bandgap measured with photoluminescence characterization at $10 \mathrm{~K}$ of a batch with: fixed V/III ratio and growth temperature variation (in black), Phosphorus BEP variations and fixed growth temperature (in red), measured with photoluminescence at 10 K.

Samples grown at 540 and $560{ }^{\circ} \mathrm{C}$ were of poor quality. In fact, at these temperatures, In and $\mathrm{P}$ desorption damage the growth front and causes increasing roughness of the material.

Optical bandgap was measured at low temperature with photoluminescence at $10 \mathrm{~K}$. Black squares (top x-axis) Fig. 2, displays the results for the influence of the temperature. Increasing the temperature from $450^{\circ} \mathrm{C}$ to $510^{\circ} \mathrm{C}$ (at a $12 \mathrm{~V} / \mathrm{III}$ ratio) causes a reduction of the optical gap from $1.97 \mathrm{eV}$ to 1.89 $\mathrm{eV}$ equivalent to a difference of $80 \mathrm{meV}$. The composition of the sample was checked by means of X-ray diffraction, only 13 $\mathrm{meV}$ is expected to result from the average composition variations of the samples grown between $450^{\circ} \mathrm{C}$ and $510^{\circ} \mathrm{C}$.

Decreasing the V/III ratio from 12 to 4.5 (at a temperature of $500^{\circ} \mathrm{C}$ ) results in a reduction of the optical bandgap too, 1.87 $\mathrm{eV}$ was observed at the lowest V/III ratio (red squares and bottom $\mathrm{x}$-axis).
Scanning Transmission Electrons Microscopy (STEM) was performed on the sample grown at a $7.3 \mathrm{~V} / \mathrm{III}$ ratio (sample A Fig. 2). STEM images exhibit contrast variations perpendicular to the growth axis, they result from composition modulation in the alloys. Present in both the AlGaInP and GaInP layer they arise from periodic changes of the In content in the alloy. At higher V/III ratio, no composition modulations were detected in the samples. Thus bandgap below $1.88 \mathrm{eV}$ results from spontaneous lateral composition modulations (LCM). Bandgap fluctuation observed with the growth temperature changes cannot be attributed to such important LCM effects as sample grown in condition B (Fig. 2) appears homogenous. However we assume that lighter composition modulation in the GaInP causes the bandgap reduction observed.

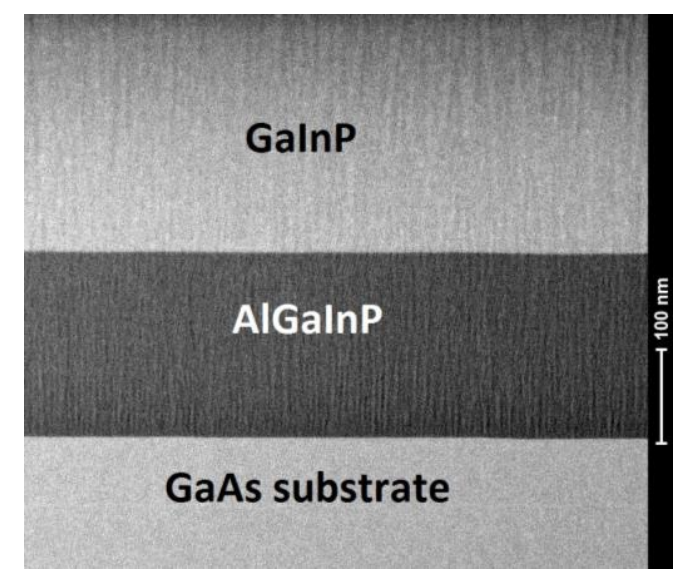

Fig. 3. STEM image of sample labeled "A" (Fig. 2), Lateral composition modulation seen in the phosphide layers.

In addition to composition fluctuations, the decrease of the V/III ratio reduces the PL intensity of the sample. Although LCM can improve carriers lifetime [7], we presume from the low PL intensity of sample A that this weak lateral composition modulation is not sufficient to benefit from carriers localization effects. It was thus chosen to keep the V/III ratio to 12 for the growth of cells.

PL spectra for the batch studying effects of growth temperature are shown Fig 4. Best PL intensity occurs at $\mathrm{Tg}=495^{\circ} \mathrm{C}$. Sample grown at $450^{\circ} \mathrm{C}$, which has highest bandgap, have the lowest PL efficiency compared to the other samples. The evolution of the PL of the samples with temperature was studied. Sample grown at $495^{\circ} \mathrm{C}$ exhibits Varshni type behavior with small unhooking to the Varshni law at low temperatures, this is often observed for phosphides presenting few localized states [9]. Sample grown at $450^{\circ} \mathrm{C}$ presents two peaks. A high energy peak with the behavior as previously described, a second peak which is only visible at low temperature and whom position exhibits an inverted S-shape. 
This inverted S-shape is characteristic of an important localized states concentration [10], [11], it evidences a concentration of localized state more important than in other samples. Moreover the low PL intensity of this sample lead to the assumption that it suffers from more non-radiative defects too. Therefore the optimal growth temperature for GaInP is from $495-500{ }^{\circ} \mathrm{C}$

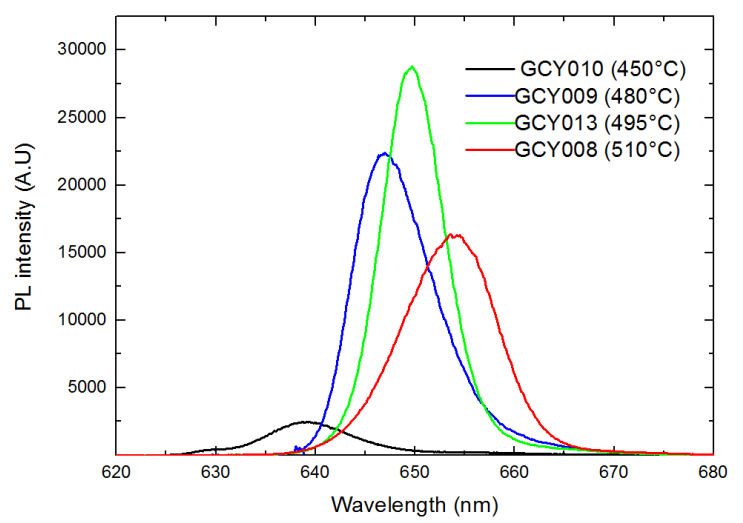

Fig. 4. PL spectra of GaInP grown at different temperatures, measured at $10 \mathrm{~K}$.

\section{B. GaInP solar cell}

The effect of growth temperatures was tested on GaInP solar cells, two identical cells were grown at $450^{\circ} \mathrm{C}$ and $500^{\circ} \mathrm{C}$. Table I details the performance gap between these cells, when grown at $450^{\circ} \mathrm{C}$ the cells have a $4.9 \%$ photoconversion efficiency with a fill factor of 0.68 , a Voc of $1.1 \mathrm{~V}$ and a short circuit current of $6.22 \mathrm{~mA} . \mathrm{cm}^{-2}$. When the cells are grown at $500{ }^{\circ} \mathrm{C}$ the cells exhibit much better characteristics, a $8.15 \mathrm{~mA} . \mathrm{cm}^{-2} \mathrm{Jsc}$, an open circuit voltage of $1.23 \mathrm{~V}$ and FF of 0.78 resulting in a $7.87 \%$ efficiency.

These results confirm that growth temperatures around $500^{\circ} \mathrm{C}$ allow to grow GaInP cells of better quality.

Work on the optimization of the structure of the GaInP single junction (not detailed here) led to further improvement of the efficiency to $9.66 \%$ without anti-reflection coating. The structure of the cell is displayed Figure 1.

TABLE I

IV CHARACTERISTICS OF GAINP CELL AT 1-SUN. EFFECT OF GROWTH TEMPERATURE ON GAINP CELL

\begin{tabular}{|c|c|c|c|c|}
\hline $\mathbf{T g}\left({ }^{\circ} \mathbf{C}\right)$ & $\begin{array}{c}\text { Jsc } \\
\left(\mathbf{m A . c m}^{-2}\right)\end{array}$ & Voc (V) & FF & $\begin{array}{c}\text { Efficiency } \\
\mathbf{( \% )}\end{array}$ \\
\hline $450^{\circ} \mathrm{C}$ & 6.22 & 1.1 & 0.68 & 4.9 \\
\hline $500^{\circ} \mathrm{C}$ & 8.15 & 1.23 & 0.78 & 7.87 \\
\hline
\end{tabular}

During the studies led for structure optimization the base was identified as the limiting factor for the cells. In order to illustrate this diagnosis, the base thickness was varied and cells with 1 $\mu \mathrm{m}, 750 \mathrm{~nm}$ and $500 \mathrm{~nm}$ base were compared.

TABLE II

IV CHARACTERISTICS OF GAINP CELL AT 1-SUN. EFFECT OF THE BASE THICKNESS

\begin{tabular}{|c|c|c|c|c|c|}
\hline $\begin{array}{c}\text { Base thickness } \\
(\mathrm{nm})\end{array}$ & $\begin{array}{c}\text { Jsc } \\
\left(\mathrm{mA} \cdot \mathrm{cm}^{-2}\right)\end{array}$ & \begin{tabular}{|c} 
Voc \\
$(V)$
\end{tabular} & FF & Woc(V) & $\begin{array}{c}\text { Efficiency } \\
(\%)\end{array}$ \\
\hline 1000 & 9.05 & 1.3 & 0.821 & 0.639 & 9.66 \\
\hline 750 & 8.74 & 1.266 & 0.807 & 0.633 & 8.93 \\
\hline 500 & 8.91 & 1.269 & 0.823 & 0.626 & 9.31 \\
\hline
\end{tabular}

Reducing the base thickness should result in a decrease of absorption and therefore a drop of both Jsc and efficiency. As detailed in Table II, the reduction of the base thickness has negligible effect on overall efficiency and only $4 \%$ photocurrent reduction occurred when halving the base thickness.

This indicates a bad base quality, where the recombination of the generated carriers limits the photocurrent collection. Indeed, the generated carriers diffusion length is believed to be so low that photons absorbed above a $500 \mathrm{~nm}$ base thickness limit do not contribute to the photocurrent.

The Woc is a parameter often used to assess the quality of solar cells. It is defined as the difference between the bandgap of the cell and its Voc [12]. The lower is Woc the better is the cell quality and value as low as $0.4 \mathrm{~V}$ are reported for performant cells. It is expressed as follows:

$$
W o c=\frac{E g}{q}-V o c
$$

Where $\mathrm{q}$ and $\mathrm{Eg}$ are elemental charge and bandgap energy, respectively.

The bandgap of the cell was estimated from the composition measured with X-ray diffraction. Table II also reports the Woc of the cells, one first notices Woc values above $0.6 \mathrm{~V}$ for all the cells, confirming a non-optimal quality of grown materials. It is noteworthy that a $13 \mathrm{mV}$ Woc decrease occurs at the lowest the base thicknesses, confirming that poor base quality limits the cell.

Final illustration to this limitation, Figure 5 gathers the EQE of the three cells of this study. They exhibit only little differences in the long wavelength range characteristic of the base response. Moreover comparing the EQE shape of the GaInP 
cells with the shape of the EQE of an AlGaAs cell we notice a more constant response with $\mathrm{AlGaAs}$ in the long wavelength range and the EQE displays a steep drop around $710 \mathrm{~nm}$. On its side GaInP cells have a slow EQE decrease starting from 500 $\mathrm{nm}$. It is clear that this results from better $\mathrm{p}$-AlGaAs compared to $\mathrm{p}$-GaInP.

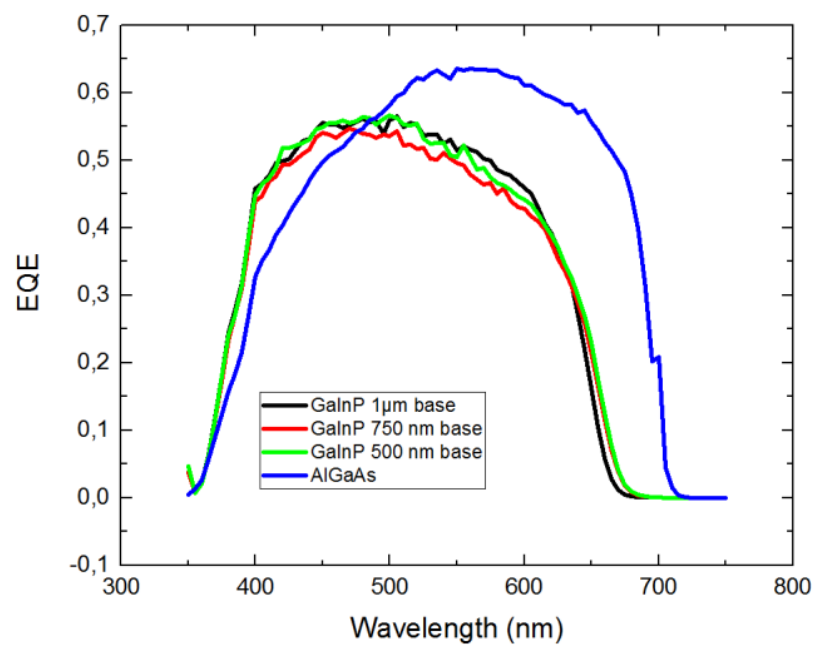

Fig. 5. EQE for GaInP cell with different base thicknesses. Comparison with 1- $\mu$ m-thick AlGaAs cell.

\section{B. Investigation on the $p-G a I n P$ limitations}

Fitting our cells response, the carriers generation and recombination profile with depth were simulated. In the base, beside the first $200 \mathrm{~nm}$ from the p-n junction, generation and recombination rates are equal. It means that in most of the base, the collection probability of photogenerated carriers is low since most of them recombine before reaching the $p-n$ junction.

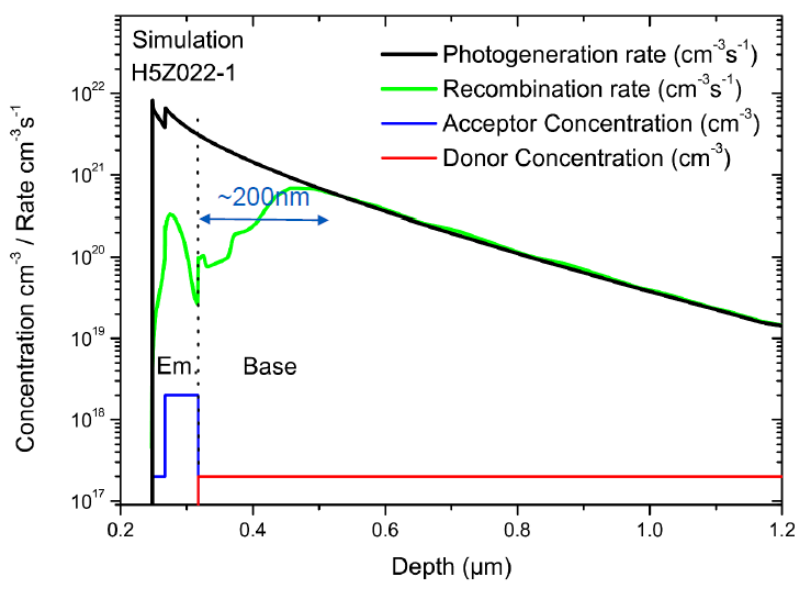

Fig. 6. Generation and recombination rates profile with depth, obtained from fitting experimental data of GaInP cell.
Time resolved fluorescence imaging (TR-FLIM) [13][14] was performed on AlInP passivated GaInP grown in the same conditions as the base layer of the cell. Using this method, we observed time-resolved PL profiles following a pulsed local illumination. Fitting the acquired transients to the continuity equation allowed to determine the lifetime and mobility in our base layer material. Despite a carrier lifetime of $2.3 \mathrm{~ns}$, we determine a diffusion length of $258 \mathrm{~nm}$ resulting from a low carrier mobility.

\section{DISCUSSION}

Despite GaInP optimization via adjustment of the growth it seems that material issues are still sources of limitations in GaInP single junction cell. Indeed several observations implicate the Be-doped GaInP as the factor limiting the conversion efficiency: between 500 and $1000 \mathrm{~nm}$, the base thickness has little impact on the photocurrent and the drop of the EQE in long wavelengths is characteristic of a poor collection of carriers generated in the base.

Studying the transport properties of the generated carriers in the p-GaInP, both cell modeling and luminescence results indicate diffusion length bellow $300 \mathrm{~nm}$ for minority carriers. It seems that this limit originates from low mobility in the GaInP alloy. We suspect that the P solid source induces the incorporation of $\mathrm{n}$ impurities (in particular $\mathrm{Si}$ and $\mathrm{S}$ ) in the $\mathrm{p}$ doped layers [15], indeed a n-type non intentional doping of $1.10^{16} \mathrm{~cm}^{-3}$ is measured in the GaInP grown. This non intentional doping needs to be compensated in order to obtain p-doped alloy and we are therefore limited to a minimum doping level of $2.10^{17} \mathrm{~cm}^{-3}$ in the base. Both majority and minority carriers mobility decrease with the doping level [8], [16]. Fig. 7 illustrates doping level effect on majority carrier mobility measured with Hall Effect. In black, the AlGaAs with lower doping levels accessible as phosphorus is not used during its growth.

Moreover for identical $\mathrm{p}$ doping levels carrier mobility is higher in AlGaAs than in GaInP (in red). Therefore we expect better carriers transport in p-doped AlGaAs, resulting in better collection of carrier generated in the base of AlGaAs cell (Fig. $5)$. 


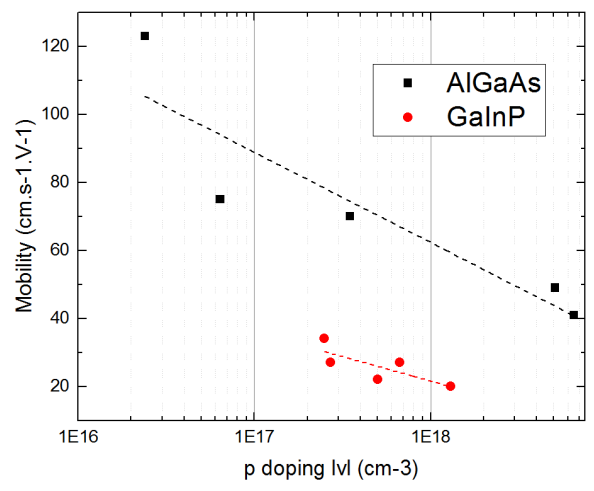

Fig. 7. Majority carrier mobility for p-doped GaInP and AlGaAs grown by MBE. Measured with Hall effect.

\section{CONCLUSION}

We report on impact of growth conditions in GaInP single junction solar cell performances. At a $1 \mu \mathrm{m} / \mathrm{h}$ growth rate best conditions were found to be $500{ }^{\circ} \mathrm{C}$ and a $12 \mathrm{~V} / \mathrm{III}$ ratio. $9.66 \%$ efficiency was obtained without anti-reflection coating. We identified p-doped GaInP as the limiting layer of the structure. Other studies comprising cell modeling and TR-FLIM led to the conclusion that small diffusion length in the solar cell prevents it from improving the photocurrent. In further work described elsewhere we explain how this limitation could be overcome structure design engineering and the use of a heterojunction.

\section{REFERENCES}

[1] B. D. Connolly James P, Mercaraglia Denis, Renard Charles, "Designing III-V multijunction solar cells on silicon," Prog. Photovoltaics Res. Appl., vol. 22, no. 7, pp. 810-820, 2014.

[2] C. Amano, K. Ando, and M. Yamaguchi, "The effect of oxygen on the properties of AlGaAs solar cells grown by molecularbeam epitaxy," J. Appl. Phys., vol. 2853, 1988.

[3] J. F. Geisz, M. A. Steiner, I. García, S. R. Kurtz, and D. J. Friedman, "Enhanced external radiative efficiency for $20.8 \%$ efficient single-junction GaInP solar cells," Appl. Phys. Lett., vol. 103, no. 4, 2013.

[4] C. Ballif et al., "Raising the one-sun conversion efficiency of III-V/Si solar cells to $32.8 \%$ for two junctions and $35.9 \%$ for three junctions," Nat. Energy, vol. 2, no. 9, p. 17144, 2017.

[5] R. Cariou et al., "III-V-on-silicon solar cells reaching 33\% photoconversion efficiency in two-terminal configuration," Nat. Energy, vol. 3, no. 4, pp. 326-333, 2018.

[6] S. F. Yoon, K. W. Mah, H. Q. Zheng, and P. H. Zhang, "Effect of V/III ratio and temperature dependence of carrier concentration in partially ordered and disordered Ga0.52In0.48P grown on GaAs substrates," J. Cryst. Growth, vol. 208, no. 1, pp. 197-204, 2000.

[7] J. D. Song, Y. W. Ok, J. M. Kim, Y. T. Lee, and T. Y. Seong, "Lateral composition modulation in GaP/InP shortperiod superlattices grown by solid source molecular beam epitaxy," J. Appl. Phys., vol. 90, no. 10, pp. 5086-5089, 2001.

[8] C. Scandrett et al., "Doping dependence and anisotropy of minority electron mobility in molecular beam epitaxygrown p type GaInP," Appl. Phys. Lett., vol. 105, no. 20, p. 202116, 2014.

[9] C. Y. Liu, S. Yuan, J. R. Dong, S. J. Chua, M. C. Y. Chan, and S. Z. Wang, "Temperature-dependent photoluminescence of GaInP/AlGaInP multiple quantum well laser structure grown by metalorganic chemical vapor deposition with tertiarybutylarsine and tertiarybutylphosphine," J. Appl. Phys., vol. 94, no. 5, pp. 2962-2967, 2003.

[10] Z. Deng et al., "Structural dependences of localization and recombination of photogenerated carriers in the top gainp subcells of GaInP/GaAs double-junction tandem solar cells," ACS Appl. Mater. Interfaces, vol. 7, no. 1, pp. 690-695, 2015.

[11] S. Minagawa, Y. Hamakawa, Y. Inoue, M. Kondow, and T. Nishino, "Anomalous temperature dependence of the ordered $\mathrm{Ga} 0.5$ In $0.5 \mathrm{P}$ photoluminescence spectrum," Appl. Phys. Lett., vol. 54, no. 18, pp. 1760$1762,2002$.

[12] R. R. King et al., "Band gap-voltage offset and energy production in next-generation multijunction solar cells," Prog. Photovoltaics Res. Appl., vol. 19, no. 7, pp. 797-812, 2011.

[13] A. Bercegol, G. El-Hajje, D. Ory, and L. Lombez, "Determination of transport properties in optoelectronic devices by time-resolved fluorescence imaging," J. Appl. Phys., vol. 122, no. 20, 2017.

[14] A. Bercegol et al., "Quantitative optical assessment of photonic and electronic properties in halide perovskite," Nat. Commun., vol. 10, no. 1, 2019.

[15] T. Martin, C. R. Stanley, A. Iliadis, C. R. Whitehouse, and D. E. Sykes, "Identification of the major residual donor in unintentionally doped InP grown by molecular beam epitaxy," Appl. Phys. Lett., vol. 46, no. 10, pp. 994996, 1985.

[16] N. M. Haegel et al., "Direct imaging of anisotropic minority-carrier diffusion in ordered GaInP," J. Appl. Phys., vol. 105, no. 2, 2009. 